Article

\title{
Epstein-Barr Virus and Human Adenovirus Viremia in Renal Tumors Is Associated with Histological Features of Malignancy
}

\author{
Piotr Kryst ${ }^{1}$, Sławomir Poletajew $1, *\left(\mathbb{D}\right.$, Aleksandra Wyczałkowska-Tomasik ${ }^{2}$, \\ Stefan Gonczar ${ }^{1}$, Maciej Wysocki ${ }^{3}$, Renata Kapuścińska ${ }^{4}$, Wojciech Krajewski ${ }^{5}$, \\ Wojciech Zgliczyński ${ }^{4}$ and Leszek Pączek ${ }^{2}$ \\ 1 Second Department of Urology, Centre of Postgraduate Medical Education, 01-809 Warsaw, Poland; \\ piotr.kryst@cmkp.edu.pl (P.K.); stefan.gonczar@gmail.com (S.G.) \\ 2 Department of Immunology, Transplantology and Internal Medicine, Medical University of Warsaw, \\ 02-005 Warsaw, Poland; atomasik@wum.edu.pl (A.W.-T.); leszek.paczek@wum.edu.pl (L.P.) \\ 3 Department of Pathology, Centre of Postgraduate Medical Education, 01-809 Warsaw, Poland; \\ maciej.wysocki@bielanski.med.pl \\ 4 Department of Endocrinology, Centre of Postgraduate Medical Education, 01-809 Warsaw, Poland; \\ renata.kapuscinska@cmkp.edu.pl (R.K.); klinendo@cmkp.edu.pl (W.Z.) \\ 5 Department of Urology and Oncological Urology, Wrocław Medical University, 50-556 Wrocław, Poland; \\ wojciech.krajewski@umed.wroc.pl \\ * Correspondence: slawomir.poletajew@cmkp.edu.pl; Tel.: +48-22-569-0148; Fax: +48-22-569-0150
}

Received: 2 September 2020; Accepted: 29 September 2020; Published: 2 October 2020

\begin{abstract}
Background: There is growing evidence that viral infections may impact the risk and clinical course of malignancies, including solid tumors. The aim of this study was to assess the possible association of selected chronic/latent viral infections with the clinical course of renal cell carcinoma (RCC). Methods: In this prospective study we enrolled 27 patients undergoing partial or radical nephrectomy due to the histologically confirmed RCC and followed them up for one year post-operation. Isolation of the nucleic acids was performed using the NucleoSpin Tissue Kit (Macherey-Nagel, Düren, Germany) from tumor tissue and using the EZ1 Virus Mini Kit v2.0 from plasma. The number of viral copies of human adenovirus (ADV), herpes simplex virus HSV-1 and HSV-2, Epstein-Barr virus (EBV), cytomegalovirus (CMV), BK virus (BKV) and John Cunningham virus (JCV) in the tissue and plasma was assessed with real-time PCR. Results: Viral infections were diagnosed in ten patients (37.0\%), including three ADV cases (11.1\%) and eight EBV cases (29.6\%). Infected patients tended to be significantly older (71.3 vs. 57.6 years, $p<0.05)$, more commonly presented with chronic renal disease (OR 2.4, $p<0.05$ ), diabetes (OR 4.2, $p<0.05$ ) and overweight (OR 2.0, $p<0.05$ ). Regarding oncological data, infected patients were found to have a higher rate of high-grade cancers (OR 5.0, $p<0.05$ ) and a higher rate of papillary RCCs (OR 8.3, $p<0.05$ ). Status of viral infections had no influence on the clinical cancer stage, surgical procedure or survival. Conclusions: EBV and ADV infections are common in renal cancer patients and increase the risk of high-grade RCC presence. While there is no significant impact on short term survival, further studies are needed to assess the relevance of these findings in a long run.
\end{abstract}

Keywords: Epstein-Barr virus; human adenovirus; polymerase chain reaction; prognosis; renal cancer

\section{Introduction}

Renal malignancies are the sixteenth most common neoplasm worldwide [1]. The most common histological type is renal cell carcinoma (RCC), arising from renal tubular epithelium and further 
divided into three main subtypes, namely clear cell, papillary and chromophobe RCC [2]. Among established risk factors, one should list smoking, arterial hypertension and obesity [3-5]. At least $6 \%$ of RCCs present germline mutations, indicating hereditary origin [6]. Among genetic alterations related to carcinogenesis, the most common is loss of chromosome $3 p$ and mutation of the von Hippel-Lindau gene at chromosome 3p25 [7]. Until now, viral infections and renal tissue viremia were not demonstrated as clear risk factors or modulators for RCC carcinogenesis. However, viral infections were linked to several malignancies, both in immunocompromised and immunocompetent patients.

It was assumed that as many as $15 \%$ of malignancies are caused by microorganisms [8]. Regarding urological cancers, viral infections seem to play a marginal role [9]. The strong association was proven only for human papilloma virus (HPV) and penile cancer risk [10]. However, more and more research shows a possible link between viral infections and urothelial cancer [11-15], prostate cancer [15-17] or testicular cancer [18,19]. Furthermore, the evidence behind the role of latent viral infections in carcinogenesis of RCC is growing. Some authors confirmed viral infection in RCC and suggest its role as a risk factor, a predictor of cancer histology and biological behavior or a consequence of immunocompromised tumor environment [20-22]. However, relation between renal cell carcinogenesis, RCC and viral infections is still to be defined.

\section{Materials and Methods}

The aim of this study was to assess the possible association of selected chronic/latent viral infections of RCC tumors with the clinical course of renal cancer.

\subsection{Patients}

In this prospective study we enrolled 27 patients undergoing the surgery due to renal tumor. Their mean age was 62.7 years, male to female ratio was $2.7: 1$. Twelve $(44.4 \%)$ and fifteen (55.6\%) patients underwent partial and radical nephrectomy, respectively. All subjects gave their informed consent for inclusion before they participated in the study. The study was conducted in accordance with the Declaration of Helsinki, and the protocol was approved by the Ethics Committee of the Medical University of Warsaw (KB/37/2017 from 7 March 2017).

Apart from the experimental methods described below, all surgical specimens were examined routinely by the urological pathologist, who eventually diagnosed RCCs in all patients, including clear cell type in 18 patients $(66.7 \%)$, papillary type in 6 patients $(22.2 \%)$ and chromophobe type in 3 patients (11.1\%). After the surgery, patients were followed up for one year, including clinical visits and laboratory tests every three months, as well as chest-abdominal CT scans at 6 and 12 months. As one patient was lost to follow up, final survival analysis was based on 26 out of 27 patients.

\subsection{Viruses}

Before the surgery, blood samples were taken from all participants and plasma were frozen at $-80^{\circ} \mathrm{C}$. After the surgery, tissue homogenates from tumor specimens were tested for the presence of human adenovirus (ADV), herpes simplex virus HSV-1 and HSV-2, Epstein-Barr virus (EBV), cytomegalovirus (CMV), BK virus (BKV) and John Cunningham virus (JCV). After diagnosing EBV and ADV infections in tissue specimens, ADV and EBV nucleic acids were sought in the corresponding plasma samples.

\subsection{Number of ADV, HSV-1/2, EBV, CMV, BKV and JCV Virus Copies in Renal Tumor Tissue}

DNA isolation from tumor tissue was performed using the NucleoSpin Tissue Kit (Macherey-Nagel, Düren, Germany), according to the manufacturer's instructions. To a tube with about $25 \mathrm{mg}$ of small pieces of tissue, $180 \mu \mathrm{L}$ of Buffer T1 and $25 \mu \mathrm{L}$ of Proteinase $\mathrm{K}$ were added. This mixture was incubated at $56^{\circ} \mathrm{C}$ for $90 \mathrm{~min}$. As a second step, $200 \mu \mathrm{L}$ of Buffer B3 was added to the lysate and incubated at $70{ }^{\circ} \mathrm{C}$ for $10 \mathrm{~min}$. Next, $210 \mu \mathrm{L}$ of ethanol $99.8 \%$ was added to the lysate (POCH, Gliwice, Poland). The sample was applied to the column and centrifuged for $1 \mathrm{~min}$ at $11,000 \times \mathrm{g}$. To wash silica membrane, 
$500 \mu \mathrm{L}$ of Buffer BW was added and centrifuged for 1 min at $11,000 \times g$, then $600 \mu \mathrm{L}$ of Buffer B5 was added to the column and centrifuged for another $1 \mathrm{~min}$ at $11,000 \times \mathrm{g}$. The silica membrane was dried by centrifugation for $1 \mathrm{~min}$ at $11,000 \times g$. The column was put in a new tube and $100 \mu \mathrm{L}$ of Buffer BE was added. It was then incubated at room temperature for $1 \mathrm{~min}$ and centrifuged $1 \mathrm{~min}$ at $11,000 \times \mathrm{g}$.

The number of ADV virus copies in the tissue was assessed with the real-time PCR method, using the primer sets and probes described previously [23]. For real-time PCR reaction we used DNA or standards, mastermix, primers and probes (sequences of primers and probes $5^{\prime}-3^{\prime}$ : GGA CGC CTC GGA GTA CCT GAG, ACA GTG GGG TTT CTG AAC TTG TT, JOE-CTG GTG CAG TTC GCC CGT GCC-TAMRA). RNase free water was used as the no template control. The reaction was run with amplification profile: $15 \mathrm{~min}$ at $95^{\circ} \mathrm{C}, 45$ cycles- $10 \mathrm{~s}$ at $95^{\circ} \mathrm{C}, 30 \mathrm{~s}$ at $55^{\circ} \mathrm{C}, 15 \mathrm{~s}$ at $72{ }^{\circ} \mathrm{C}$. The viral load of ADV was automatically calculated by the analyzer CFX96Dx Real Time PCR Detection System (BioRad, Hercules, CA, USA) relative to the standard curve.

The number of HSV-1/2 and EBV virus copies in the tissue was assessed with the real-time PCR method, using the diagnostic test R-gene Kit (bioMérieux, Marcy l'Etoile, France) according to the manufacturer's instructions. For real-time PCR reaction we used DNA or standards, mastermix, primers and probes. RNase free water was used as the no template control. The reaction was run with amplification profile: $15 \mathrm{~min}$ at $95^{\circ} \mathrm{C}, 45$ cycles- $10 \mathrm{~s}$ at $95^{\circ} \mathrm{C}, 40 \mathrm{~s}$ at $60^{\circ} \mathrm{C}$. The viral load of HSV-1/2 and EBV was automatically calculated by the analyzer D $\times 96$ (BioRad, Hercules, CA, USA) relative to the standard curve.

The number of CMV, BKV and JCV virus copies in the tissue were assessed with the real-time PCR method, using the diagnostic test GeneProof PCR Kit (GeneProof, Brno, Czech Republic) according to the manufacturer's instructions. For real-time PCR reaction we used DNA or standards, mastermix, primers and probes. RNase free water was used as the no template control. The reaction was run with amplification profile: $2 \mathrm{~min}$ at $37^{\circ} \mathrm{C}, 10 \mathrm{~min}$ at $95^{\circ} \mathrm{C}, 45$ cycles- $5 \mathrm{~s}$ at $95^{\circ} \mathrm{C}, 40 \mathrm{~s}$ at $60^{\circ} \mathrm{C}, 20 \mathrm{~s}$ at $72{ }^{\circ} \mathrm{C}$. The viral load of CMV, BKV and JCV was automatically calculated by the analyzer ABI7500 (Applied Biosystems, Foster City, CA, USA) relative to the standard curve.

\subsection{Number of EBV and ADV Virus Copies in Plasma}

Isolation of viral nucleic acids from plasma was performed using EZ1 Virus Mini Kit v2.0 (Qiagen, Hilden, Germany), according to the manufacturer's instructions with EZ1 BioRobot device (Qiagen, Hilden, Germany). All reactions were run in automatic apparat.

Real-time PCR reaction described above for CMV, BKV and JCV diagnosis were adopted also for assessment of EBV and ADV virus copies in the plasma. As the study was focused on local viremia as a potential prognostic factor for renal cancer, only parameters that were positive in tissue were evaluated in plasma.

\subsection{Calculation of Viral Load}

The viral load of all viruses in tissue and plasma was automatically calculated by the analyzer relative to the standard curves, which were as follows:

- human adenovirus (ADV): 500, 5000, 50,000, 500,000 cp/mL,

- herpes simplex virus-1 (HSV-1): 2, 20, 200, $2000 \mathrm{cp} / \mu \mathrm{L}$,

- herpes simplex virus-2 (HSV-2): 2, 20, 200, $2000 \mathrm{cp} / \mu \mathrm{L}$,

- Epstein-Barr virus (EBV): 10, 100, 1000, 10,000 cp/ $\mu \mathrm{L}$,

- cytomegalovirus (CMV): 10, 100, 1000, 10,000 cp/ $\mu \mathrm{L}$,

- $\quad$ BK virus (BKV): 10, 100, 1000, 10,000 cp/ $\mu \mathrm{L}$,

- John Cunningham virus (JCV): 10, 100, 1000, 10,000 cp/ $\mu \mathrm{L}$. 


\subsection{Statistical Analysis}

Results are presented as absolute values, percentages and mean or median values for variables with or without normal distribution, respectively. Normal distribution was tested with Shapiro-Wilk test. Levene test was applied to assess the equality of variances. For comparisons between study groups, unpaired $t$-test and Pearson test were used for quantitative and qualitative variables, respectively. A $p$ value of $<0.05$ was considered statistically significant.

\section{Results}

Viral sequences within tumors were diagnosed in tissue specimens from ten patients $(37.0 \%)$, including eight cases of EBV (29.6\%) and three cases of ADV (11.1\%). In one patient concomitant EBV and ADV viral sequences were found. For all other examined infections, the results were negative. Serum tests were also negative for viral sequences in all patients. Results of viral tests are presented in Table 1.

Table 1. Viral infections in renal cell carcinoma (RCC) tissues.

\begin{tabular}{ccc}
\hline & Total Number of Positive Cases & Mean Value of the Viral Copy Numbers/uL \\
\hline EBV & 8 & 198.3 (range 29-829) \\
ADV & 3 & 619.7 (range 393-867) \\
HSV-1 & 0 & - \\
HSV-2 & 0 & - \\
CMV & 0 & - \\
BKV & 0 & - \\
JCV & 0 & - \\
\hline
\end{tabular}

Of note, infected patients tended to be significantly older (71.3 vs. 57.6 years, $p<0.05$ ), more commonly presented chronic renal disease ( $70 \%$ vs. $29 \%$, OR $2.4, p<0.05)$, diabetes $(50 \%$ vs. $12 \%$, OR $4.2, p<0.05)$ and overweight ( $80 \%$ vs. $41 \%$, OR $2.0, p<0.05)$. Table 2 presents a comparison of patients depending on status and etiology of viral infection.

Regarding oncological data, infected patients were found to have a higher rate of poorly differentiated cancers defined as high-grade $(60 \%$ vs. $12 \%$, OR 5.0, $p<0.05)$. Simultaneously, there was a higher rate of papillary RCC in this group of patients ( $50 \%$ vs. $6 \%$, OR $8.3, p<0.05$ ). Status of viral infection had no influence on clinical stage of renal cancer or surgical procedure (partial vs. radical nephrectomy).

When analyzing separately ADV and EBV infections, only the impact on the rate of chronic kidney disease remained statistically significant for ADV $(100 \%$ vs. $29 \%$, OR 3.4, $p<0.05)$, while EBV infection increased the rate of high-grade cancers $(63 \%$ vs. $12 \%$, OR 5.3, $p<0.05)$ with simultaneous higher rate of diabetes ( $63 \%$ vs. $12 \%$, OR 5.3, $p<0.05)$ and overweight $(88 \%$ vs. $41 \%$, OR $2.1, p<0.05)$. 
Table 2. Comparison of patients depending on status and etiology of viral infection.

\begin{tabular}{|c|c|c|c|c|c|c|c|}
\hline Parameter & $\begin{array}{c}\text { Non-Infected } \\
\text { Patients (Controls) } \\
(n=17)\end{array}$ & $\begin{array}{l}\text { Infected Patients } \\
\text { (ADV or/and EBV } \\
\text { Infection) }(n=10)\end{array}$ & $\begin{array}{l}p \text {-Value (Controls } \\
\text { vs. ADV/EBV) }\end{array}$ & $\begin{array}{l}\text { Patients with ADV } \\
\text { Infection }(n=3)\end{array}$ & $\begin{array}{c}p \text {-Value (ADV } \\
\text { Positive vs. ADV } \\
\text { Negative Patients) }\end{array}$ & $\begin{array}{l}\text { Patients with EBV } \\
\text { Infection }(n=8)\end{array}$ & $\begin{array}{c}p \text {-Value (EBV } \\
\text { Positive vs. EBV } \\
\text { Negative Patients) }\end{array}$ \\
\hline Percentage of women & $41.2 \%$ & $30.0 \%$ & $>0.05$ & $66.7 \%$ & $>0.05$ & $25.0 \%$ & $>0.05$ \\
\hline Mean age (years) & 57.6 & 71.3 & 0.02 & 73.3 & $>0.05$ & 69.9 & $>0.05$ \\
\hline Mean BMI $\left(\mathrm{kg} / \mathrm{m}^{2}\right)$ & 24.5 & 27.9 & 0.01 & 26.7 & $>0.05$ & 28.3 & 0.01 \\
\hline $\begin{array}{l}\text { Percentage of } \\
\text { overweight patients } \\
\left(\mathrm{BMI}>25 \mathrm{~kg} / \mathrm{m}^{2}\right)\end{array}$ & $41.2 \%$ & $80.0 \%$ & 0.0499 & $66.7 \%$ & $>0.05$ & $87.5 \%$ & 0.03 \\
\hline $\begin{array}{l}\text { Percentage of patients } \\
\text { with diabetes }\end{array}$ & $11.8 \%$ & $50.0 \%$ & 0.02 & $33.3 \%$ & $>0.05$ & $62.5 \%$ & 0.006 \\
\hline $\begin{array}{l}\text { Percentage of patients } \\
\text { with uncontrolled } \\
\text { dyslipidemia }\end{array}$ & $41.2 \%$ & $10.0 \%$ & $>0.05$ & $0 \%$ & $>0.05$ & $12.5 \%$ & $>0.05$ \\
\hline $\begin{array}{l}\text { Median white blood cell } \\
\text { count }(\mathrm{k} / \mathrm{uL})\end{array}$ & 8.79 & 6.14 & $>0.05$ & 10.04 & $>0.05$ & 5.97 & 0.049 \\
\hline $\begin{array}{l}\text { Median hemoglobin } \\
\text { concentration (g/dL) }\end{array}$ & 13.8 & 13.1 & $>0.05$ & 13.3 & $>0.05$ & 13.1 & $>0.05$ \\
\hline $\begin{array}{l}\text { Percentage of abnormal } \\
\text { CRP values }(>5 \mathrm{mg} / \mathrm{L})\end{array}$ & $23.5 \%$ & $30.0 \%$ & $>0.05$ & $66.7 \%$ & $>0.05$ & $12.5 \%$ & $>0.05$ \\
\hline $\begin{array}{l}\text { Median creatinine } \\
\text { serum concentration } \\
(\mathrm{mg} / \mathrm{dL})\end{array}$ & 0.76 & 1.09 & 0.047 & 1.11 & $>0.05$ & 1.08 & $>0.05$ \\
\hline $\begin{array}{c}\text { Percentage of patients } \\
\text { with chronic kidney } \\
\text { disease }(\mathrm{GFR}<60 \\
\left.\mathrm{mL} / \mathrm{min} / 1.73 \mathrm{~m}^{2}\right)\end{array}$ & $29.4 \%$ & $70.0 \%$ & 0.04 & $100 \%$ & 0.04 & $62.5 \%$ & $>0.05$ \\
\hline $\begin{array}{l}\text { Percentage of patients } \\
\text { with proteinuria } \\
(>30 \mathrm{mg} / \mathrm{dL})\end{array}$ & $23.5 \%$ & $20.0 \%$ & $>0.05$ & $33.3 \%$ & $>0.05$ & $12.5 \%$ & $>0.05$ \\
\hline $\begin{array}{l}\text { Percentage of patients } \\
\text { with hematuria } \\
\text { (>3 erythrocytes/HPF) }\end{array}$ & $41.2 \%$ & $50.0 \%$ & $>0.05$ & $66.7 \%$ & $>0.05$ & $50.0 \%$ & $>0.05$ \\
\hline $\begin{array}{l}\text { Percentage of patients } \\
\text { with pyuria } \\
\text { (>5 leukocytes/HPF) }\end{array}$ & $35.3 \%$ & $50.0 \%$ & $>0.05$ & $66.7 \%$ & $>0.05$ & $37.5 \%$ & $>0.05$ \\
\hline
\end{tabular}


Table 2. Cont

\begin{tabular}{|c|c|c|c|c|c|c|c|}
\hline Parameter & $\begin{array}{c}\text { Non-Infected } \\
\text { Patients (Controls) } \\
(n=17)\end{array}$ & $\begin{array}{l}\text { Infected Patients } \\
\text { (ADV or/and EBV } \\
\text { Infection) }(n=10)\end{array}$ & $\begin{array}{l}p \text {-Value (Controls } \\
\text { vs. ADV/EBV) }\end{array}$ & $\begin{array}{l}\text { Patients with ADV } \\
\text { Infection }(n=3)\end{array}$ & $\begin{array}{c}p \text {-Value (ADV } \\
\text { Positive vs. ADV } \\
\text { Negative Patients) }\end{array}$ & $\begin{array}{l}\text { Patients with EBV } \\
\text { Infection }(n=8)\end{array}$ & $\begin{array}{c}p \text {-Value (EBV } \\
\text { Positive vs. EBV } \\
\text { Negative Patients) }\end{array}$ \\
\hline \multirow{7}{*}{$\begin{array}{l}\text { Pathological stage } \\
\text { of cancer }\end{array}$} & pT1a-58.8\% & pT1a-20\% & \multirow{7}{*}{$>0.05$} & pT1a-0\% & \multirow{7}{*}{$>0.05$} & pT1a-25.0\% & \multirow{7}{*}{$>0.05$} \\
\hline & pT1b-23.5\% & pT1b-20\% & & pT1b-33.3\% & & pT1b-12.5\% & \\
\hline & pT2a-5.9\% & pT2a-20\% & & pT2a-33.3\% & & pT2a-12.5\% & \\
\hline & pT2b-5.9\% & pT2b-10\% & & pT2b-33.3\% & & pT2b-12.5\% & \\
\hline & рТ3a- $5.9 \%$ & рT3a-20\% & & рТЗа-0\% & & pT3a- $-25.0 \%$ & \\
\hline & pT3b-4-0\% & рT3b-4-0\% & & pT3b-4-0\% & & pT3b-4-0\% & \\
\hline & missing- $0 \%$ & missing-10\% & & missing- $0 \%$ & & missing-12.5\% & \\
\hline $\begin{array}{l}\text { Histological grade } \\
\text { of cancer }\end{array}$ & $\begin{array}{l}\text { low grade- }-76.5 \% \\
\text { high grade-11.8\% } \\
\text { missing- } 11.8 \%\end{array}$ & $\begin{array}{l}\text { low grade- }-40.0 \% \\
\text { high grade- } 60.0 \% \\
\text { missing- }-0 \%\end{array}$ & 0.01 & $\begin{array}{l}\text { low grade- }-33.3 \% \\
\text { high grade- } 66.7 \%\end{array}$ & $>0.05$ & $\begin{array}{l}\text { low grade- }-37.5 \% \\
\text { high grade- } 62.5 \%\end{array}$ & 0.02 \\
\hline $\begin{array}{c}\text { Histological RCC } \\
\text { subtype }\end{array}$ & $\begin{array}{c}\text { clear cell- }-76.5 \% \\
\text { papillary- }-5.9 \% \\
\text { chromophobe- } 17.6 \% \\
\text { other- } 0 \%\end{array}$ & $\begin{array}{c}\text { clear cell- } 40.0 \% \\
\text { papillary-50.0\% } \\
\text { chromophobe- } 0 \% \\
\text { other- } 10.0 \%\end{array}$ & 0.004 & $\begin{array}{c}\text { clear cell- }-33.3 \% \\
\text { papillary-66.7\% } \\
\text { chromophobe- } 0 \% \\
\text { other- } 0 \%\end{array}$ & $>0.05$ & $\begin{array}{c}\text { clear cell- }-50.0 \% \\
\text { papillary-37.5\% } \\
\text { chromophobe-0\% } \\
\text { other-12.5\% }\end{array}$ & $>0.05$ \\
\hline Surgical procedure & $\begin{array}{c}\text { partial } \\
\text { nephrectomy-47.1\% } \\
\text { radical } \\
\text { nephrectomy-52.9\% }\end{array}$ & $\begin{array}{c}\text { partial } \\
\text { nephrectomy-40.0\% } \\
\text { radical } \\
\text { nephrectomy-60.0\% }\end{array}$ & $>0.05$ & $\begin{array}{c}\text { partial } \\
\text { nephrectomy-33.3\% } \\
\text { radical } \\
\text { nephrectomy-66.7\% }\end{array}$ & $>0.05$ & $\begin{array}{c}\text { partial } \\
\text { nephrectomy-37.5\% } \\
\text { radical } \\
\text { nephrectomy- } 62.5 \%\end{array}$ & $>0.05$ \\
\hline $\begin{array}{l}\text { 12-month cancer } \\
\text { recurrence rate }\end{array}$ & $12.5 \%$ & $10.0 \%$ & $>0.05$ & $\mathrm{~T}^{\mathrm{S}}$ & $>0.05$ & $12.5 \%$ & $>0.05$ \\
\hline
\end{tabular}




\section{Discussion}

With increasing evidence on the impact of a variety of viral infections on cancer development and limited data on the relationship between viral infections and RCC, we have conducted a prospective study aimed at the assessment of the incidence of selected viral infections within renal tumors. We have found that EBV and ADV tumor infections are common and are associated with different histological cancer features.

While there are some data regarding the link between EBV infection and renal malignancy, to the best of our knowledge the association of ADV with renal tumors is raised for the first time. ADV usually causes acute self-limiting infections with mild clinical symptoms within the eyes, respiratory or gastrointestinal tract. However, in some cases ADV can establish a latency within T lymphocytes [24]. For this reason, it is advised to differentiate ADV infection from disease [25].

The ADV infections and reinfections are more common and have more severe clinical course in immunocompromised patients, i.e., after organ transplantation [26,27]. We hypothesized that alterations within the immune system related to carcinogenesis can increase a risk of viral infections. This can explain a high rate of ADV presence in renal tumors, that we have noted in our study. The role of ADV infection in cancers is poorly understood and our study highlights the need of future research.

Much more is known in the field of EBV and cancer. After primary infection, EBV causes a lifelong asymptomatic latent infection within memory B lymphocytes [28]. It is assumed that $95 \%$ of the healthy adult population is infected [29]. This can be associated with latent gene heterogeneity and deletions. A special interest was focused on the loss of function of LMP1, EBNA3B, EBNA2 and B95-8 suppressor genes [30-33]. In some cases, especially in the context of immunodeficiency, such infection can promote carcinogenesis, i.e., Burkitt's lymphoma, nasopharyngeal carcinoma, Hodgkin's disease and others [34]. Latent EBV infection also increases the risk of gastric cancer, so called EBV-associated gastric carcinoma, which nowadays accounts for $2-20 \%$ of gastric cancer cases and is associated with a relatively good prognosis [35-37]. Simultaneously, EBV was detected in numerous tumors, including lymphoid, epithelial and mesenchymal tumors [34]. The first report on the causative role of EBV infection in kidney carcinogenesis in transgenic mice was published in 1997 by Törnell et al. [38].

The relation between EBV infection and renal cancer was previously reported [20-22,39,40]. What we did find is that EBV infection within renal tumors is frequent and associated with high-grade tumors. Shimakage et al. noted EBV infection within 100\% of renal tumors [21]. On the contrary, Salehipoor et al. did not find any case of EBV infection among 49 renal cancer patients [22]. Kim et al. found that EBV virus could be a marker of sarcomatoid RCC, as it is present in tumor-infiltrating B cells due to local modulation of immune response [20]. On the other hand, Karaarslan et al. observed EBV infection in $48 \%$ of RCCs, including the presence of EBV DNA in tumor cells in $22 \%$ of cases [39]. Kang et al. noticed EBV presence in both tumor cells and tumor-infiltrating lymphocytes in $34 \%$ of RCC patients and the later phenomenon was found to be an independent prognostic factor of poor patient survival [40]. Finally, Becker et al. showed that EBV infection of renal proximal tubular cells may participate in evoking a cellular immune response that results in a damaged renal interstitium in patients with chronic interstitial nephritis [41]. Taking all these data together, it remains unclear whether EBV infection is a cause or a result of RCC development and whether the infection is specific for tumor cells, B lymphocytes, renal parenchyma or all of them.

Apart from the finding that RCCs are infected with EBV and ADV, we did show that these infections lead to a higher rate of high-grade cancers. Therefore, one can expect shorter survival in these patients as cancer grade is one the most important prognostic factors in postoperative follow-up [42,43]. This was already proven by Kang et al., who noticed significantly shorter overall survival in RCC patients and EBV infected tumor-infiltrating lymphocytes [40].

We have also noted that patients with viral infections have a higher rate of chronic renal disease. However, this fact can be at least partially attributed not to virus, but to other differences in patient characteristics, including older age, higher rate of diabetes and being overweight. All these facts are well known risk factors for renal disease. This explanation is supported by a study from 
Blazquez-Navarro et al., which showed that EBV has no significant impact on the risk of renal failure in patients after renal transplantation [44].

This study is not free from limitations. First, the study population is limited. However, for a pilot study with seven viruses tested, this limitation is justified to some extent. For future studies, one should plan to focus on EBV and ADV and enroll more patients. Second, as study methods clearly diagnosed or excluded viral infections in tissue homogenates, no information was gathered on whether viral genetic material comes from cancer cells, infiltrative lymphocytes or other cells. This doubt does not change substantially the clinical meaning of our findings. However, it needs to be addressed in the future. Third, the selection of tested viruses was subjective and does not rule out the importance of other viral infections in renal malignancies. Until now, the possible association between renal carcinogenesis and HPV infection [8] or hepatitis C virus infection [45] was suggested.

\section{Conclusions}

EBV and ADV viremia in RCC tumors is common and it is associated with the risk of high-grade malignancy. While there is no significant impact on short term survival, further studies are needed to assess the relevance of these findings in the long term.

Author Contributions: Conception-P.K.; Design of work-A.W.-T., M.W., R.K., W.Z., L.P.; Acquisition-P.K., A.W.-T., S.G., W.Z., L.P.; Interpretation of data-S.P., A.W.-T., M.W., R.K., W.K., W.Z., L.P.; Analysis-P.K., S.P.; Manuscript preparation-S.P., W.K.; Manuscript revision-P.K., S.P., A.W.-T., W.K., W.Z., L.P. All authors have read and agreed to the published version of the manuscript.

Funding: This research received no external funding.

Conflicts of Interest: The authors declare no conflict of interest.

\section{References}

1. Bray, F.; Ferlay, J.; Soerjomataram, I.; Siegel, R.L.; Torre, L.A.; Jemal, A. Global cancer statistics 2018: GLOBOCAN estimates of incidence and mortality worldwide for 36 cancers in 185 countries. CA Cancer J. Clin. 2018, 68, 394-424. [CrossRef] [PubMed]

2. Moch, H.; Cubilla, A.L.; Humphrey, P.A.; Reuter, V.E.; Ulbright, T.M. The 2016 WHO Classification of Tumours of the Urinary System and Male Genital Organs-Part A: Renal, Penile, and Testicular Tumours. Eur. Urol. 2016, 70, 93-105. [CrossRef] [PubMed]

3. Hidayat, K.; Du, X.; Zou, S.Y.; Shi, B.M. Blood pressure and kidney cancer risk: Meta-analysis of prospective studies. J. Hypertens. 2017, 35, 1333-1344. [CrossRef] [PubMed]

4. Cumberbatch, M.G.; Rota, M.; Catto, J.W.; La Vecchia, C. The Role of Tobacco Smoke in Bladder and Kidney Carcinogenesis: A Comparison of Exposures and Meta-analysis of Incidence and Mortality Risks. Eur. Urol. 2016, 70, 458-466. [CrossRef]

5. Gild, P.; Ehdaie, B.; Kluth, L.A. Effect of obesity on bladder cancer and renal cell carcinoma incidence and survival. Curr. Opin. Urol. 2017, 27, 409-414. [CrossRef]

6. Huang, K.L.; Mashl, R.J.; Wu, Y.; Ritter, D.I.; Wang, J.; Oh, C.; Paczkowska, M.; Reynolds, S.; Wyczalkowski, M.A.; Oak, N.; et al. Pathogenic Germline Variants in 10,389 Adult Cancers. Cell 2018, 173, 355-370. [CrossRef]

7. Brugarolas, J. Molecular genetics of clear-cell renal cell carcinoma. J. Clin. Oncol. 2014, 32, $1968-1976$. [CrossRef]

8. Pisani, P.; Parkin, D.M.; Muñoz, N.; Ferlay, J. Cancer and infection: Estimates of the attributable fraction in 1990. Cancer Epidemiol. Biomark. Prev. 1997, 6, 387-400.

9. Alibek, K.; Karatayeva, N.; Bekniyazov, I. The role of infectious agents in urogenital cancers. Infect. Agent Cancer 2012, 7, 35. [CrossRef]

10. Cai, T.; Di Vico, T.; Durante, J.; Tognarelli, A.; Bartoletti, R. Human papilloma virus and genitourinary cancers: A narrative review. Minerva Urol. Nefrol. 2018, 70, 579-587. [CrossRef]

11. Li, N.; Yang, L.; Zhang, Y.; Zhao, P.; Zheng, T.; Dai, M. Human papillomavirus infection and bladder cancer risk: A meta-analysis. J. Infect. Dis. 2011, 204, 217-223. [CrossRef] [PubMed] 
12. Jørgensen, K.R.; Jensen, J.B. Human papillomavirus and urinary bladder cancer revisited. APMIS 2020, 128, 72-79. [CrossRef] [PubMed]

13. Shen, C.H.; Wu, J.D.; Hsu, C.D.; Jou, Y.; Lin, C.; Wang, M.; Wu, S.; Chan, M.W.Y.; Chiang, M.; Fang, C.; et al. The high incidence of JC virus infection in urothelial carcinoma tissue in Taiwan. J. Med. Virol. 2011, 83, 2191-2199. [CrossRef]

14. Geetha, D.; Tong, B.C.; Racusen, L.; Markowitz, J.S.; Westra, W.H. Bladder carcinoma in a transplant recipient: Evidence to implicate the BK human polyomavirus as a causal transforming agent. Transplantation 2002, 73, 1933-1936. [CrossRef] [PubMed]

15. Zapatka, M.; Borozan, I.; Brewer, D.S.; Murat Iskar, A.G.; Iskar, M.; Grundhoff, A.; Alawi, M.; Desai, N.; Sültmann, H.; Moch, H.; et al. The landscape of viral associations in human cancers. Nat. Genet. 2020, 52, 320-330. [CrossRef] [PubMed]

16. Yin, B.; Liu, W.; Yu, P.; Liu, C.; Chen, Y.; Duan, X.; Liao, Z.; Chen, Y.; Wang, X.; Pan, X.; et al. Association between human papillomavirus and prostate cancer: A meta-analysis. Oncol. Lett. 2017, 14, 1855-1865. [CrossRef]

17. Russo, G.I.; Calogero, A.E.; Condorelli, R.A.; Scalia, G.; Morgia, G.; La Vignera, S. Human papillomavirus and risk of prostate cancer: A systematic review and meta-analysis. Aging Male 2020, 23, 132-138. [CrossRef] [PubMed]

18. Garolla, A.; Vitagliano, A.; Muscianisi, F.; Valente, U.; Ghezzi, M.; Andrisani, A.; Ambrosini, G.; Foresta, C. Role of Viral Infections in Testicular Cancer Etiology: Evidence from a Systematic Review and Meta-Analysis. Front. Endocrinol. 2019, 10, 355. [CrossRef]

19. Strickler, H.D.; Schiffman, M.H.; Shah, K.V.; Rabkin, C.S.; Schiller, J.T.; Wacholder, S.; Clayman, B.; Viscidi, R.P. A survey of human papillomavirus 16 antibodies in patients with epithelial cancers. Eur. J. Cancer Prev. 1998, 7, 305-313. [CrossRef]

20. Kim, K.H.; Han, E.M.; Lee, E.S.; Park, H.S.; Kim, I.; Kim, Y.S. Epstein-Barr virus infection in sarcomatoid renal cell carcinoma tissues. BJU Int. 2005, 96, 547-552. [CrossRef]

21. Shimakage, M.; Kawahara, K.; Harada, S.; Sasagawa, T.; Shinka, T.; Oka, T. Expression of Epstein-Barr virus in renal cell carcinoma. Oncol. Rep. 2007, 18, 41-46. [CrossRef] [PubMed]

22. Salehipoor, M.; Khezri, A.; Behzad-Behbahani, A.; Geramizadeh, B.; Rahsaz, M.; Aghdaei, M.; Afrasiabi, M.A. Role of viruses in renal cell carcinoma. Saudi J. Kidney Dis. Transpl. 2012, 23, 53-57. [PubMed]

23. Heim, A.; Ebnet, C.; Harste, G.; Pring-Akerblom, P. Rapid and quantitative detection of human adenovirus DNA by real-time PCR. J. Med. Virol. 2003, 70, 228-239. [CrossRef] [PubMed]

24. Lion, T. Adenovirus infections in immunocompetent and immunocompromised patients. Clin. Microbiol. Rev. 2014, 27, 441-462. [CrossRef] [PubMed]

25. Matthes-Martin, S.; Feuchtinger, T.; Shaw, P.J.; Engelhard, D.; Hirsch, H.H.; Cordonnier, C.; Ljungman, P. European guidelines for diagnosis and treatment of adenovirus infection in leukemia and stem cell transplantation: Summary of ECIL-4 (2011). Transpl. Infect. Dis. 2012, 14, 555-563. [CrossRef] [PubMed]

26. Florescu, D.F.; Stohs, E.J. Approach to infection and disease due to adenoviruses in solid organ transplantation. Curr. Opin. Infect. Dis. 2019, 32, 300-306. [CrossRef] [PubMed]

27. Watcharananan, S.P.; Avery, R.; Ingsathit, A.; Malathum, K.; Chantratita, W.; Mavichak, V.; Chalermsanyakorn, P.; Jirasiritham, S.; Sumethkul, V. Adenovirus disease after kidney transplantation: Course of infection and outcome in relation to blood viral load and immune recovery. Am. J. Transplant. 2011, 11, 1308-1314. [CrossRef]

28. Yao, Q.Y.; Rickinson, A.B.; Epstein, M.A. A re-examination of the Epstein-Barr virus carrier state in healthy seropositive individuals. Int. J. Cancer 1985, 35, 35-42. [CrossRef]

29. Kanda, T.; Yajima, M.; Ikuta, K. Epstein-Barr virus strain variation and cancer. Cancer Sci. 2019, 110, 1132-1139. [CrossRef]

30. Feederle, R.; Klinke, O.; Kutikhin, A.; Poirey, R.; Tsai, M.H.; Delecluse, H.J. Epstein-Barr Virus: From the Detection of Sequence Polymorphisms to the Recognition of Viral Types. Curr. Top. Microbiol. Immunol. 2015, 390, 119-148.

31. White, R.E.; Rämer, P.C.; Naresh, K.N.; Meixlsperger, S.; Pinaud, L.; Rooney, C.; Savoldo, B.; Coutinho, R.; Bödör, C.; Gribben, J.; et al. EBNA3B-deficient EBV promotes B cell lymphomagenesis in humanized mice and is found in human tumors. J. Clin. Investig. 2012, 122, 1487-1502. [CrossRef] [PubMed] 
32. Kelly, G.L.; Milner, A.E.; Baldwin, G.S.; Bell, A.I.; Rickinson, A.B. Three restricted forms of Epstein-Barr virus latency counteracting apoptosis in c-myc-expressing Burkitt lymphoma cells. Proc. Natl. Acad. Sci. USA 2006, 103, 14935-14940. [CrossRef] [PubMed]

33. Lo, A.K.; Dawson, C.W.; Jin, D.Y.; Lo, K.W. The pathological roles of BART miRNAs in nasopharyngeal carcinoma. J. Pathol. 2012, 227, 392-403. [CrossRef] [PubMed]

34. Murray, P.G.; Young, L.S. Epstein-Barr virus infection: Basis of malignancy and potential for therapy. Expert. Rev. Mol. Med. 2001, 3, 1-20. [CrossRef]

35. Fukayama, M.; Hayashi, Y.; Iwasaki, Y.; Chong, J.; Ooba, T.; Takizawa, T.; Koike, M.; Mizutani, S.; Miyaki, M.; Hirai, K. Epstein-Barr virus-associated gastric carcinoma and Epstein-Barr virus infection of the stomach. Lab. Investig. 1994, 71, 73-81.

36. Murphy, G.; Pfeiffer, R.; Camargo, M.C.; Rabkin, C.S. Meta-analysis shows that prevalence of Epstein-Barr virus-positive gastric cancer differs based on sex and anatomic location [published correction appears in Gastroenterology. 2011 Mar;140(3):1109]. Gastroenterology 2009, 137, 824-833. [CrossRef]

37. Camargo, M.C.; Kim, W.H.; Chiaravalli, A.M.; Kim, K.; Corvalan, A.H.; Matsuo, K.; Yu, J.; Sung, J.J.Y.; Herrera-Goepfert, R.; Meneses-Gonzalez, F.; et al. Improved survival of gastric cancer with tumour Epstein-Barr virus positivity: An international pooled analysis. Gut 2014, 63, 236-243. [CrossRef]

38. Törnell, J.; Farzad, S.; Espander-Jansson, A.; Matejka, G.; Isaksson, O.; Rymo, L. Expression of Epstein-Barr nuclear antigen 2 in kidney tubule cells induce tumors in transgenic mice. Oncogene 1996, 12, 1521-1528.

39. Karaarslan, S.; Şen, N. Investigation of the relationship of Epstein-Barr virus with in situ hybridization in renal-cell carcinomas. Ann. Diagn. Pathol. 2018, 34, 45-49. [CrossRef]

40. Kang, M.J.; Kim, K.M.; Bae, J.S.; Park, H.S.; Lee, H.; Chung, M.J.; Moon, W.S.; Lee, D.G.; Jang, K.Y. Tumor-infiltrating PD1-Positive Lymphocytes and FoxP3-Positive Regulatory T Cells Predict Distant Metastatic Relapse and Survival of Clear Cell Renal Cell Carcinoma. Transl. Oncol. 2013, 6, $282-289$. [CrossRef]

41. Becker, J.L.; Miller, F.; Nuovo, G.J.; Josepovitz, C.; Schubach, W.H.; Nord, E.P. Epstein-Barr virus infection of renal proximal tubule cells: Possible role in chronic interstitial nephritis. J. Clin. Investig. 1999, 104, 1673-1681. [CrossRef] [PubMed]

42. Zisman, A.; Pantuck, A.J.; Dorey, F.; Chao, D.H.; Gitlitz, B.J.; Moldawer, N.; Lazarovici, D.; deKernion, J.B.; Figlin, R.A.; Belldegrun, A.S. Mathematical model to predict individual survival for patients with renal cell carcinoma. J. Clin. Oncol. 2002, 20, 1368-1374. [CrossRef] [PubMed]

43. Frank, I.; Blute, M.L.; Cheville, J.C.; Lohse, C.M.; Weaver, A.L.; Zincke, H. An outcome prediction model for patients with clear cell renal cell carcinoma treated with radical nephrectomy based on tumor stage, size, grade and necrosis: The SSIGN score. J. Urol. 2002, 168, 2395-2400. [CrossRef]

44. Blazquez-Navarro, A.; Dang-Heine, C.; Wittenbrink, N.; Bauer, C.; Wolk, K.; Sabat, R.; Westhoff, T.H.; Sawitzki, B.; Reinke, P.; Thomusch, O.; et al. BKV, CMV, and EBV Interactions and their Effect on Graft Function One Year Post-Renal Transplantation: Results from a Large Multi-Centre Study. EBioMedicine 2018, 34, 113-121. [CrossRef]

45. Wijarnpreecha, K.; Nissaisorakarn, P.; Sornprom, S.; Thongprayoon, C.; Thamcharoen, N.; Maneenil, K.; Podboy, A.J.; Cheungpasitporn, W. Hepatitis C infection and renal cell carcinoma: A systematic review and meta-analysis. World J. Gastrointest. Pathophysiol. 2016, 7, 314-319. [CrossRef] [PubMed]

(C) 2020 by the authors. Licensee MDPI, Basel, Switzerland. This article is an open access article distributed under the terms and conditions of the Creative Commons Attribution (CC BY) license (http://creativecommons.org/licenses/by/4.0/). 